\title{
Analysis of the Potential Use of STEM Approach in Biology Lessons Refers to Development of Science in Indonesia
}

\author{
Muhammad Umar Wakhid ${ }^{1, *}$ Suhartini' ${ }^{2}$ Nuraini Nadhiroh ${ }^{3}$ \\ ${ }^{1}$ Master of Biology Education, Faculty of Mathematics and Natural Sciences, Universitas Negeri Yogyakarta, \\ Indonesia \\ ${ }^{2}$ Department of Biology Education, Faculty of Mathematics and Natural Sciences, Universitas Negeri \\ Yogyakarta, Indonesia \\ ${ }^{3}$ Master of Physic Education, Faculty of Mathematics and Natural Sciences, Universitas Negeri Yogyakarta, \\ Indonesia \\ *Corresponding author. Email: Muhammadumar.2019@student.uny.ac.id
}

\begin{abstract}
This study aims to determine the development and effectiveness of STEM in biology learning, referring to the development of STEM in science in Indonesia. This research is a literature study that examines some research articles that are compatible with the research theme. The research sample was taken purposively based on items related to the research theme, the research journal articles used came from searches on google scholar data, totaling 45 articles with a range of the last five years (2016-2020). The results of this study indicate that the most widely conducted research is to test the impact, influence, or effectiveness of $55.56 \%$, the most commonly used research design is the quasi-experimental $44.90 \%$, the data collection technique uses the $51.47 \%$ test, the most data analysis using N-gain $33.33 \%$, the learning model that is most integrated with STEM is PjBL $31.11 \%$, the effectiveness of STEM application in biology learning is dominated by the effectiveness of increasing learning outcomes $20 \%$, $18 \%$ creative thinking, $14 \%$ understanding of concepts. Based on the analysis of the results, it can be projected that STEM will also be able to improve critical thinking skills, communication skills, mathematical skills, environmental literacy, scientific literacy, creativity, science process skills, argument skills, conservation character, misconceptions, scientific attitudes, and collaboration.
\end{abstract}

Keywords: STEM, Effectiveness of the STEM

\section{INTRODUCTION}

Entering the industrial revolution 4.0, the world has experienced relatively rapid development where information technology has become the basis of human life. This development also demands integrated and technology-based learning. The STEM (Science, Technology, Engineering, mathematics) approach is one of the updated topics following the 4.0 revolution era to compete globally and solve life issues through STEM literacy [1]. STEM literacy, as expressed by Bybee, shows concepts, principles, and techniques from science, technology, engineering, and mathematics that are used in an integrated manner in the development of products, processes, and systems in life[2]. The STEM approach can create a cohesive and active learning system because all four aspects are needed simultaneously to solve problems [3].

Learning objectives with the STEM approach are suitable for secondary school learning, where learning subjects require intricate knowledge [3]. Following curriculum 2013, the use of technology in biological, chemical, physical, and mathematical learning activities is also necessary to support active and innovative learning situations [4]. In recent years many have used STEM in learning at every level of education. This situation is shown from the research results that reveal that STEM application can improve students' academic and non-academic achievement.[5].

The application of STEM, which was initially only intended to increase students' interest in the STEM field, became wider. This situation arises because, after 
applying in reapplying able to improve knocantery, apply knowledge to solve problems and encourage students to create something new. Various learning methods can support STEM application. Besides that, STEM, integrative STEM different learning methods can support its application[6], [7]. Apedoe, X. S., et al., 2008 said that the et al. rated STEM learning approach could equip students' 21 st-century work skills through learning outcomes. [8]. Learning outcomes indicate the ability of student work skills, the extent to which the influence of STEM learning on learning outcomes in the form of creativity, problem-solving skills, and students' self-motivation to think critically.

Many researchers and academics in Indonesia have researched STEM. Various articles and research journals seek to find in-depth information about applying or using the STEM approach in Indonesia, especially in learning biology, chemistry, physics, and mathematics, provide information related to STEM. Based on this, researchers are interested in revealing the STEM approach's effectiveness if applied to biology learning based on the development of science in Indonesia by analyzing various STEM-related research articles and journals obtained from the google scholar database.

\section{RESEARCH METHOD}

This article is a literature study that discusses STEM (Science Technology Engineering and Mathematics) in learning biology, chemistry, physics, and mathematics in Indonesia to provide information about STEM-based and integrated learning in Indonesia. The literature study method examines previous studies similar to this research and is a literature study from reliable sources. The steps in this research can be explained as follows:

\subsection{Preparation Phase}

The preparation stage is collecting data in journal articles, National and International Seminars sourced from searches on google scholar indexed by SCOPUS, DOAJ, ISSN Journal, or other journal indexers regarding STEM in Biology, Chemistry, Physics, and Mathematics learning in the last five years. (20162020), The sample selection in this study used a purposive technique because the sample was adjusted to the research theme. Keywords used are STEMbased learning, STEM integration, Biology Learning, Chemistry, Physics.

\subsection{Implementation Stage}

At the implementation stage, the articles that have been collected are selected based on predetermined criteria, namely research objectives, research design, data collection techniques, data analysis techniques,
STEM implementation techniques, and STEM application in learning. The articles are grouped to facilitate data analysis. This study's data analysis is descriptive qualitative, with a total number of 45 items analyzed.

\section{RESULT AND DISCUSSION}

A literature study of 45 articles that discusses STEM in biology learning refers to the development of science in Indonesia. It is based on research objectives, research design, data collection techniques, data analysis, STEM implementation, and STEM's effectiveness in the learning process. The results of grouping based on these criteria can be presented as follows.

\subsection{The Potential Use of STEM-based on Research Objectives}

Based on the research objectives, the results obtained were as much as $55.56 \%$ of the research objectives used were to examine the impact, influence, or effectiveness of the STEM approach to the dependent variable. Research with this objective compares the results after treatment and before treatment, whether there is an increase or not. The research objective is to test the impact, influence, or effectiveness of being said to be useful if the experimental class shows better results than the control class, and it is said that there is an effect if there is a very significant difference between the practical course and the control class.

The purpose of STEM to describe is $20 \%$, identical to literature studies that want to dig more in-depth about applying the STEM approach in education and find out which learning models and topics can be integrated with the STEM approach. STEM aims to develop $13.3 \%$. The development carried out, in this case, is the product in the field of learning strategies, learning tools, and development of STEM-based learning media to be applied in learning biology, chemistry, physics, and mathematics. Research that aims to develop the average uses the R $\mathrm{n}$ D (Research and Development) design.

The research objective with the STEM approach in Indonesia, which is applied to learning, especially science learning, is dominated by research to examine the impact or effectiveness of the STEM approach on student learning outcomes or variables related to cognitive, affective, and psychomotor abilities. In addition to reviewing the result of research with the STEM approach in Indonesia, many also use development methods to develop teaching tools in ways, media, and other teaching materials that allow integration with a STEM-based system. 
Table 1. Potential analysis based on research objectives

\begin{tabular}{|c|l|c|c|}
\hline No & $\begin{array}{l}\text { Research } \\
\text { purposes }\end{array}$ & Frequency & $\begin{array}{l}\text { Percentage } \\
\text { (\%) }\end{array}$ \\
\hline 1 & $\begin{array}{l}\text { Testing Impact / } \\
\text { Effect / } \\
\text { Effectiveness }\end{array}$ & 25 & $55.56 \%$ \\
\hline 2 & Develop & 6 & $13.33 \%$ \\
\hline 3 & $\begin{array}{l}\text { Develop and } \\
\text { test the impact }\end{array}$ & 2 & $4.44 \%$ \\
\hline 4 & Increase & 3 & $6.67 \%$ \\
\hline 5 & Describe & 45 & $100 \%$ \\
\hline \multicolumn{2}{|l|}{ amount } & & \\
\hline
\end{tabular}

This objective-based analysis can reflect the development of research using the STEM approach that most researchers are interested in.

\subsection{The Potential Use of STEM-Based Research Design}

The research design most used in STEM research is Quasi-experimental with $44.90 \%$. Quasiexperiments are experiments with a treatment, impact measurement, experimental unit but do not use random assignments to create comparisons to infer changes due to treatment[9]. This quasi-experimental study used a practical class and a randomly selected control class [10], [11]. The least research design used in STEM research was the mixed method [14] and the $2.04 \%$ survey. Meanwhile, the development design ( $\mathrm{R}$ \& D) was $18.37 \%$.

Table 2. Potential analysis based on research design

\begin{tabular}{|c|c|c|c|}
\hline No & Research design & Frequency & Percentage (\%) \\
\hline \multirow[t]{4}{*}{1} & \multicolumn{3}{|c|}{ Experiment } \\
\hline & a. Experimental & 2 & $4.08 \%$ \\
\hline & b. Pre-experimental & 4 & $8.16 \%$ \\
\hline & c. Quasi-experiment & 22 & $44.90 \%$ \\
\hline 2 & $R \& D$ & 9 & $18.37 \%$ \\
\hline 3 & Survey & 1 & $2.04 \%$ \\
\hline 4 & Mixed-Method & 1 & $2.04 \%$ \\
\hline 5 & Case study & 2 & $4.08 \%$ \\
\hline 6 & Classroom Action Riset & 2 & $4.08 \%$ \\
\hline 7 & Analysis & 6 & $12.24 \%$ \\
\hline & amount & 49 & $100 \%$ \\
\hline
\end{tabular}

The tabulation of data based on the analysis presented in Table 2 shows that the research design is highly dependent and adjusted to the research objectives. Experimental research designs are the most suitable designs to determine the impact, influence, or effectiveness of a model, method, or approach to the variables the researcher wants to measure. The most widely used experimental design is the quasiexperimental design because it compares the control class and the practical class. With such a method, it will be easy to determine the effect or effect.

\subsection{The Potential Use of STEM-Based Data Collection and Analysis Techniques}

The results of the analysis showed that the most widely used test instrument was $51.47 \%$. The test instrument in research related to the use of STEM in research used to measure critical thinking skills, creative thinking skills, conceptual understanding, mathematical abilities, scientific literacy, misconceptions, and student learning outcomes. The second most widely used data collection technique is a questionnaire used to look at communication skills, creativity, argumentative skills, conservation character, scientific attitudes, and collaboration. Overall, data collection techniques are tests, questionnaires, observation, documentation, field notes, literature study, and interviews.

The data analysis used the most $\mathrm{N}$-gain, namely $33.33 \%$, and the least used was the Anava test, Wilcoxon test, and the effect size of $2.08 \%$. The data analysis used depends on the research objectives, the formulation of the problem, and the research hypothesis. In this study, the data analysis used was Ngain, t-test, qualitative descriptive, quantitative descriptive, MANOVA, z test, effect size, ANOVA, and Wilcoxon. 
The $\mathrm{N}$-gain test is the most widely used in this study. $\mathrm{N}$ gain is a test that aims to determine the effectiveness of a method or treatment in research using experimental designs in the form of real experiments, pre-experiments, or quasi-experiments. The $\mathrm{N}$-gain test is performed by calculating the difference between pretest and post-test values before and after applying the method or treatment.

Tabel 3. Potential analysis based on data collection techniques

\begin{tabular}{|c|l|c|c|}
\hline No & Data collection technique & Frequency & Percentage (\%) \\
\hline 1 & Questionnaire & 20 & $29.41 \%$ \\
\hline 2 & Observation & 5 & $7.35 \%$ \\
\hline 3 & Test & 4 & $51.47 \%$ \\
\hline 4 & Literature review & 2 & $5.88 \%$ \\
\hline 5 & Interview & 1 & $2.94 \%$ \\
\hline 6 & Documentation & 1 & $1.47 \%$ \\
\hline 7 & Fieldnotes & 68 & $1.47 \%$ \\
\hline & Amount & & $100 \%$ \\
\hline
\end{tabular}

Tabel 4. Potential analysis based on data analysis

\begin{tabular}{|c|l|c|c|}
\hline No & Data Analysis & Frequency & $\begin{array}{l}\text { Percentage } \\
(\%)\end{array}$ \\
\hline 1 & Anava & 1 & $2.08 \%$ \\
\hline 2 & Uji-t & 11 & $22.92 \%$ \\
\hline 3 & $\begin{array}{l}\text { Qualitative } \\
\text { Descriptive }\end{array}$ & 11 & $22.92 \%$ \\
\hline 4 & $\begin{array}{l}\text { Quantitative } \\
\text { Descriptive }\end{array}$ & 2 & $4.17 \%$ \\
\hline 5 & N-Gain & 16 & $33.33 \%$ \\
\hline 6 & Manova & 1 & $2.08 \%$ \\
\hline 7 & Uji-z & 2 & $4.17 \%$ \\
\hline 8 & Validity & 2 & $4.17 \%$ \\
\hline 9 & Effect size & 1 & $2.08 \%$ \\
\hline 10 & Wilcoxon & 1 & $2.08 \%$ \\
\hline \multicolumn{2}{|l|}{ Amount } & 48 & $100 \%$ \\
\hline
\end{tabular}

By looking at the difference in cost, it can be seen whether the technique or therapy is effective or not.

\subsection{Potential Use of STEM Based on STEM Implementation}

The implementation of STEM teaching in biology learning refers to the natural science approach in Indonesia can be seen in table 5. The results of 45 journal articles that have analyzed the implementation of STEM in learning show that $44.44 \%$ use the STEM approach alone in the application and the development of STEM in education. The integration of STEM that is integrative with the learning model is also carried out to increase STEM effectiveness in learning [15] because STEM as an approach does not have a syntax while the learning model has it.

Tabel 5. Usage analysis based on stem implementation

\begin{tabular}{|l|l|c|c|}
\hline No & $\begin{array}{l}\text { Implementation } \\
\text { of STEM }\end{array}$ & Frequency & $\begin{array}{l}\text { Percentage } \\
(\%)\end{array}$ \\
\hline 1 & STEM only & 20 & $44.44 \%$ \\
\hline 2 & $\begin{array}{l}\text { STEM with } \\
\text { problem-based } \\
\text { learning }\end{array}$ & 9 & $20.00 \%$ \\
\hline 3 & $\begin{array}{l}\text { STEM with } \\
\text { project-based } \\
\text { learning }\end{array}$ & 14 & $31.11 \%$ \\
\hline 4 & $\begin{array}{l}\text { STEM With } \\
\text { Inquiry }\end{array}$ & 2 & $4.44 \%$ \\
\hline \multicolumn{2}{|l}{ Amount } & 45 & $100 \%$ \\
\hline
\end{tabular}

The integrated learning model is STEM with PjBl $31.11 \%$, STEM with PBL $20.00 \%$, and STEM with inquiry $4.44 \%$. To achieve the learning objectives, the researcher combines STEM with other models such as PBL, PjBL, Inquiry to make it more suitable for the topic being studied so that the results are more effective. 


\subsection{Potential Use of STEM Based on The Effectiveness of The Application of STEM in Learning}

The effectiveness of STEM in learning based on journals that have been analyzed is either STEM as a stand-alone approach or STEM combined with a learning model. The point of STEM in learning from this study can be seen in table 6 .

Table 6. The effectiveness of the application of stem in learning

\begin{tabular}{|c|c|c|c|}
\hline No & $\begin{array}{l}\text { Implementation } \\
\text { of STEM }\end{array}$ & Frequency & $\begin{array}{l}\text { Percentage } \\
\text { (\%) }\end{array}$ \\
\hline 1 & $\begin{array}{l}\text { Critical Thinking } \\
\text { Skills }\end{array}$ & 5 & $10.00 \%$ \\
\hline 2 & $\begin{array}{l}\text { Creative } \\
\text { Thinking Skills }\end{array}$ & 9 & $18.00 \%$ \\
\hline 3 & $\begin{array}{l}\text { Communication } \\
\text { skills }\end{array}$ & 2 & $4.00 \%$ \\
\hline 4 & $\begin{array}{l}\text { Mathematical } \\
\text { Ability }\end{array}$ & 2 & $4.00 \%$ \\
\hline 5 & $\begin{array}{l}\text { Environmental } \\
\text { Literacy }\end{array}$ & 1 & $2.00 \%$ \\
\hline 6 & $\begin{array}{l}\text { Concept of } \\
\text { Understanding }\end{array}$ & 8 & $16.00 \%$ \\
\hline 7 & Science Literacy & 3 & $6.00 \%$ \\
\hline 8 & $\begin{array}{l}\text { Learning } \\
\text { outcomes }\end{array}$ & 10 & $20.00 \%$ \\
\hline 9 & Creativity & 1 & $2.00 \%$ \\
\hline 10 & $\begin{array}{l}\text { Science Process } \\
\text { Insights }\end{array}$ & 2 & $4.00 \%$ \\
\hline 11 & Argument Skills & 2 & $4.00 \%$ \\
\hline 12 & $\begin{array}{l}\text { Concert } \\
\text { Characters }\end{array}$ & 1 & $2.00 \%$ \\
\hline 13 & Misconception & 1 & $2.00 \%$ \\
\hline 14 & $\begin{array}{l}\text { The attitude of } \\
\text { science }\end{array}$ & 1 & $2.00 \%$ \\
\hline 15 & Collaboration & 2 & $4.00 \%$ \\
\hline \multicolumn{2}{|r|}{ Amount } & 50 & $100 \%$ \\
\hline
\end{tabular}

\subsubsection{STEM Enhances Critical Thinking}

STEM improves critical thinking; the STEMbased approach can improve students' critical thinking and increase students' critical thinking from students' post-test results after using STEM in learning. Some studies combine STEM with models or methods to improve critical thinking, as did I.mu'minah (2019) that ICT-assisted STEM can enhance critical thinking[12]. PjBl combined with STEM can enhance critical thinking due to scientific investigation steps to make students more active and creative [13].

\subsubsection{STEM Enhances Creative Thinking}

STEM can improve creative thinking. Creative thinking is one of the manifestations of higher-order thought because creative thinking can think creatively and with the highest cognitive competence. To find out, a person's creative thinking ability is shown through the product of his thought or creativity to produce something new[10]. STEM-PjBL can improve creative thinking because, in the STEM-PjBL learning process, there are stages of implementing testing. When conducting trials, students will determine whether the tool is made to function correctly or not; when something does not work, then the device is reviewed to be fixed. It will stimulate and improve the creative thinking of students [12]. Ariani (2019) states that STEM-PBL effectively improves creative thinking skills in good categories [14].

\subsubsection{STEM Improves Learning Outcomes}

STEM is effective in improving student learning outcomes, both cognitive, affective, and psychomotor. The effectiveness of increasing learning outcomes in biology, chemistry, physics, and mathematics is obtained based on hands-on activity in the STEM approach, which positively impacts students' understanding of the material. Several studies have been conducted by w. Nessa (2017)[15], Susanti (2018)[16], tiara Adelita (2017)[17], which integrates STEM with problem-based learning models, show that STEM-PBL can improve student learning outcomes. Learning using the STEM approach can increase the creativity and innovation of students[18].

\subsubsection{STEM Improves Environmental Literacy}

Environmental literacy provides students with an understanding of the main concepts of natural phenomena and the application of knowledge. The existence of a sense of ecological literacy makes it easier to solve environmental problems with unlimited sources through technology [19]. STEM provides meaningful learning in ecological literacy. STEM learning also offers a broad knowledge of 
environmental issues. Environmental problem solving through STEM is determining environmental problems, initiating solution ideas, designing problem solutions, and creating products to overcome ecological problems [20]. The understanding of ecological literacy has better collaborated with STEM [21].

\subsubsection{STEM Improves Scientific Literacy}

Scientific literacy has an essential role in the $21 \mathrm{st}$ century. Scientific literacy is an important thing to master because of its complete application and almost all fields. [22]. STEM with scientific literacy provides maximum results on student learning outcomes [23]. Students become more aware of the environment, more critical in investigating and solving good results [24]. Learning using a virtual lab can also be a solution in the learning process to increase students' scientific literacy. Virtual labs with STEM are also useful in improving students' scientific literacy. The learning implementation becomes more attractive and valuable for students [25].

\subsubsection{STEM Improves Communication Skills}

The ability to communicate is a skill that must be possessed by students in the 21 st century. Students have communication skills that support their success in problem-solving [26]. Problem-solving is done by conveying what he knows well and structured manner, either orally, in writing, with the media, or without the press. The ability to communicate with STEM provides a more diverse range of learning [27]. Students can take advantage of technology to develop vocabulary in their knowledge. The standard of learners in communication becomes higher. Communication will run better because students understand broadly through STEM knowledge [28].

\subsubsection{STEM Improves Mathematical Abilities}

The development of education has led to various breakthroughs and innovations, especially for mathematical abilities through STEM. Mathematical skills with STEM provide solutions to problems in life to Mathematical notation language. These problems will be solved using relevant mathematical concepts [29]. Learning with STEM allows students to construct their knowledge, collect facts, develop data, and present findings. The flow of thinking of students in mathematical abilities is better and orderly [30].

\subsubsection{STEM improves Concept Mastery}

Each student has their way of capturing and understanding learning material. The understanding of each student becomes heterogeneous. Mastery of concepts is needed in increasing students' knowledge of a material [31]. Mastery of concepts will increase when students learn on a STEM basis[32]. STEMbased learning provides students with solutions to difficulties in the understanding of division and problem-solving. The use of STEM-based teaching materials also significantly affects students' mastery of concepts [33]. Students will have extensive knowledge through access to technology in the form of the internet, then analyze with science and mathematics and project assignments by making simple props [34] available in teaching materials. Besides, STEM, which is applied in learning, can improve science process skills [13], argument skills [35], concert character, misconceptions[36], an attitude of science [37], and collaboration [12].

The STEM approach to education, especially in biology learning, has proven to improve students' skills in the cognitive, affective, and psychomotor domains. The STEM approach that is oriented towards technology, science, and engineering is constructive for the gifts of students and can increase the profile of 21 st-century skills and is following the goals of the 2013 curriculum which emphasizes perfecting the mindset which discusses strengthening interactive learning, strengthening active learning seeking, strengthening multimedia learning that, of course, related to technology and critical learning emphasis. The most visible effect in this journal's analysis is that STEM can increase cognitive learning outcomes; besides that, the STEM approach is combined with a learning model, especially emphasizing project-based learning, problem-based learning, and inquiry resulting in active and interactive learning. Dynamic and interactive learning is obtained from students' activities, directly observing objects in their environment and combined with technology to produce products.

\section{CONCLUSION}

A discussion of this research can be concluded that the development of science and technology in Indonesia also has implications for the potential use of the STEM approach in Indonesia. The results of literature studies from articles and research journals related to the STEM approach to learning biology have increased significantly from year to year. Therefore, 
the results of this study illustrate that STEM research is carried out by many researchers to determine the impact, influence, or effectiveness of learning by $55.56 \%$, research designs that are widely used are $44.90 \%$ quasi-experimental, data collection techniques using $51.47 \%$ tests, implementation of the STEM-based approach. 44.44\%, STEM combined with PjBL and PBL $51.11 \%$, the effectiveness of STEM in learning biology to improve learning outcomes $20 \%, 18 \%$ creative thinking, $16 \%$ understanding of concepts, $10 \%$ critical thinking, STEM also enhances communication skills, mathematical skills, environmental literacy, scientific literacy, creativity, science process skills, argument skills, conservation character, misconceptions, scientific attitudes, and collaboration.

\section{REFERENCES}

[1] Hanover Research, K-12 STEM Education Overview, 2011.

[2] R.W. Bybee, Challenges and Opportunities The Case for Education, National Science Teachers Association (NSTA) Press, 2013.

[3] J. Simarmata, L. Simanihuruk, R. Ramadhani, M. Safitri, D. Wahyuni, A. Iskandar, Pembelajaran STEM berbasis HOTS dan Penerapannya, Yayasan Kita Menulis, 2020.

[4] E.D. Pitaloka, S. Suyanto, Meta Analisis: Blended Learning Pada Pembelajaran Biologi, Kimia, Fisika, dan Matematika di Indonesia, Jurnal Pendidikan Biologi 11(1) (2019) 32-39.

[5] P.C. Lam, D. Doverspike, J. Zhao, J. Zhe, C.C. Menzemer, An Evaluation of A STEM Program for Middle School Students on Learning Disability Related IEPs, Journal of STEM Education 9(1\&2) (2008) 21-29.

[6] J.R. Ruiz-Gallardo, S. Castaño, J.J. GómezAlday, A. Valdés, Assessing Student Workload in Problem Based Learning: Relationships Among Teaching Method, Student Workload and Achievement, A case study in Natural Sciences, Teaching and Teacher Education 27(3) (2011) 619-627. DOI: https://doi.org/10.1016/j.tate.2010.11.001

[7] S.S. Urena, C. Melanie, R. Stevens, Effect of Cooperative Problem-based Laboratorium Instruction on Metacognition and ProblemSolving Skills, Journal of Chemical Education 89(6) (2012) 700-706. DOI: https://doi.org/10.1021/ed1011844
[8] X.S. Apedoe, B. Reynolds, M.R. Ellefson, C.D. Schunn, Bringing Engineering Design into High School Science Classrooms: The Heating/Cooling Unit, Journal of Science Education and Technology 17(5) (2008) 454465. DOI: https://doi.org/10.1007/s10956-0089114-6

[9] D. Thomas, T. Donald, Campbell, Cook, QuasiExperimentation: Design \& Analysis Issues for Field Settings, Houghton Mifflin Company, 1979.

[10] Y. Sukmawijaya, Suhendar, A. Juhanda, Pengaruh Model Pembelajaran STEM-PJBL Terhadap Kemampuan Berpikir Kreatif Siswa, Jurnal Program Studi Pendidikan Biologi 9(9) (2019) 28-43.

[11] N. Farachax, Kartimia, A. Mulyani, Penerapan Assessment Kinerja dalam Pembelajaran Biologi Berbasis STEM (Science, Technology, Engineering, dan Mathematics) untuk Meningkatkan Keterampilan Proses Sains Siswa Pada Sub Konsep Sistem Indera Kelas XI di MAN 1 Kota Cirebon, Jurnal Ilmu Alam Indonesia 2(1) (2019) 36-49.

[12] I.H. Mu'minah, I. Aripin, Implementasi pembelajaran IPA berbasis science, technology, engineering and mathematic (STEM) berbantuan ICT untuk meningkatkan keterampilan abad 21 pada siswa madrasah tsanawiyah (MTs), in: Prosiding Seminar Matematika dan Sains Departemen Pendidikan Matematika dan Pendidikan Biologi FKIP Universitas Wiralodra, 2019, pp. 92-97.

[13] Sumardiana, A. Hidayat, Parno, Kemampuan Berpikir Kritis pada Model Project Based Learning disertai STEM Siswa SMA pada Suhu dan Kalor, Jurnal Pendidikan: Teori, Penelitian, dan Pengembangan 04(7) (2019) 874-879.

[14] L. Ariani, Sudarmin, S. Nurhayati, Analisis Berpikir Kreatif Pada Penerapan Problem Based Learning berpendekatan Science, Technology, Engineering, and Mathematics, Jurnal Inovasi Pendidikan Kimia 13(1) (2019) 2307-2317.

[15] W. Nessa, Y. Hartono, C. Hiltrimartin, Pengembangan Buku Siswa Materi Jarak pada Ruang Dimensi Tiga Berbasis Science, Technology, Engineering, and Mathematics (STEM) Problem-Based Learning di Kelas X, Jurnal Elemen 3(1) (2017). DOI: https://doi.org/10.29408/jel.v3i1.273

[16] L.Y. Susanti, Penerapan Media Pembelajaran Kimia Berbasis Science, Technology, Engineering, and Mathematics (STEM) Untuk 
Meningkatkan Hasil Belajar Siswa SMA/SMK Pada Materi Reaksi Redoks, Jurnal Pendidikan Sains 6(2) (2018) 32. DOI: https://doi.org/10.26714/jps.6.2.2018.32-40

[17] T. Adelita, T. Suhery, A. Ibrahim, Pengembangan Strategi Pembelajaran dengan Pendekatan STEM- Problem Based Learning Pada Materi Laju Reaksi di Kelas XI SMA, Jurnal Penelitian Pendidikan Kimia: Kajian Hasil Penelitian Pendidikan Kimia 4 (2) (2017) 105 110.

[18] T.L. Larkin, Creativity in STEM Education: Reshaping the Creative Project, in: Proceedings of 2015 International Conference on Interactive Collaborative Learning, IEEE, Piscataway, New Jersey, 2015, pp. 1184-1189. DOI: https://doi.org/10.1109 / ICL. 2015.7318203

[19] R. Farwati, A. Permanasari, H. Firman, T. Suhery, Integrasi Problem Based Learning dalam STEM Education Berorientasi pada Aktualisasi Literasi Lingkungan dan Kreativitas, in: Prosiding Seminar Nasional Pendidikan IPA STEM untuk pembelajaran SAINS Abad 21, Universitas Sriwijaya, 2017, pp. 198-206.

[20] H. Jang, J.A. Paulson, Identifying $21^{\text {st }}$ Century STEM Competencies Using Workplace Data, Journal of Science Education and Technology, 25(2) (2015) 284-301.

[21] H. Nizar, Somakim, M. Yusuf, Pengembangan LKPD dengan Model Discovery Learning Pada Materi Irisan Dua Lingkaran, Jurnal Elemen 2(2) (2016)

[22] M.Y.B. Amri, A. Rusilowati, Wiyanto, Penerapan Model Pembelajaran Conceptual Understanding Procedures untuk Meningkatkan Kemampuan Literasi Sains Siswa SMP di Kabupaten Tegal, Unnes Physiscs Education Journal 6(3) (2017).

[23] Lutfi, Ismail, A.A. Azis, Pengaruh project based learning terintegrasi stem terhadap literasi sains, kreativitas dan hasil belajar peserta didik, in: Prosiding Seminar Nasional Biologi dan Pembelajarannya (2017) 189-194.

[24] J. Afriana, A. Permanasari, A. Fitriani, Penerapan Project Based Learning Terintegrasi STEM Untuk Meningkatkan Literasi Sains Siswa Ditinjau Dari Gender, Jurnal Inovasi Pendidikan IPA 2(2) (2016) 202.

[25] I. Ismail, A. Permanasari, W. Setiawan, Effectiveness STEM-Based Virtual Lab in Improving the Scientific Literacy of Students with Gender Differences, Jurnal Inovasi
Pendidikan IPA 2(2) (2016) 190-201.

[26] S. Hartati, A. Ilham, S. Haji, Pemecahan Masalah Mahasiswa dan 2 Dosen Program Studi Pascasarjana Pendidikan Matematika Fkip UNIB, Jurnal of Mathematics, Education, Science Technology 2(1) (2017) 43-72. DOI: http://dx.doi.org/10.30651/must.v2i1.403

[27] A. Bicer et al., The Effects of STEM PBL on Students' Mathematical and Scientific Vocabulary Knowledge, International Journal of Contemporary Educational Research 2(2) (2015) 69-75.

[28] D. Triana, Y.U. Anggraito, S. Ridlo, Effectiveness of Environmental Change Learning Tools Based on STEM-PjBL Towards 4C Skills of Students, Journal of Innovative Science Education 9(37) (2019) 244-249.

[29] Khairani, Mukhni, F.Q. Aini, Pembelajaran Berbasis Stem Dalam Perkuliahan Kalkulus Di Perguruan Tinggi, UNINUS Journal 03 (2018) 104-111.

[30] N. Nurdini, I.M. Sari, I. Suyana, The effectiveness of physics e-book that contains balance of scientific literacy aspects in increasing scientific literacy skills: A case study to 32 students in one of public senior high school in Bandung, in: International Conference on Mathematics and Science Education of Universitas Pendidikan Indonesia, vol. 3, Sekolah Pascasarjana Universitas Pendidikan Indonesia, 2018, pp. 276-280.

[31] I.D. Astuti, T. Toto, L. Yulisma, Model Project Based Learning Terintegrasi STEM Untuk Meningkatkan Penguasaan Konsep dan Aktivitas Belajar Siswa, Jurnal Pendidikan dan Biologi 11(2) (2019) 93, DOI: https://doi.org/10.25134/quagga.v11i2.1915

[32] R. Sagala, R. Umam, A. Thahir, A. Saregar, I. Wardani, The Effectiveness of STEM-Based on Gender Differences: The Impact of Physics Concept Understanding, European Journal of Educational Research 8(3) (2019) 753-761. DOI: https://doi.org/10.12973/eu-jer.8.3.753

[33] K.I. Pangesti, D. Yulianti, Sugianto, Bahan Ajar Berbasis STEM (Science, Technology, Engineering, and Mathematics) untuk Meningkatkan Penguasaan Konsep Siswa SMA, Unnes Physic Education Journal 6(3) (2017) 5358 .

[34] A. Tipani, T. Toto, L. Yulisma, Implementasi Model PjBL Berbasis STEM Untuk Meningkatkan Penguasaan Konsep dan 
Kemampuan Berpikir Analitis Siswa, Journal of Science and Biology Education 4(2) (2019) 7076.

[35] A.K. Paramita, I.W. Dasna, Yahmin, Kajian Pustaka: Integrasi STEM Untuk Keterampilan Argumentasi dalam Pembelajaran Sains, Jurnal pembelajaran Kimia 4(2) (2019) 92-99.

[36] M. Taufiq, S. Muntamah, P. Parmin, Remediation of misconception on straight line motion concept using guided inquiry model assisted by student worksheet based on science technology engineering and mathematics (STEM) on junior high school students, in: Journal of Physics: Conference Series, vol. 1521, IOP Publishing, Bristol, 2020, pp. 042039. DOI: https://doi.org/10.1088/17426596/1521/4/04203 $\underline{9}$

[37] A. Thahir, C. Anwar, A. Saregar, L. Choiriah, F. Susanti, A. Pricilia, The Effectiveness of STEM Learning: Scientific Attitudes and Students' Conceptual Understanding, in: Journal of Physics: Conference Series, vol. 1467, IOP Publishing, Bristol, 2020, pp. 012008. DOI: https://doi.org/10.1088/17426596/1467/1/01200 $\underline{8}$ 